\title{
TEORI PEKERJAAN SOSIAL DALAM LINTASAN MODERNISME DAN POSMODERNISME
}

Oleh:

Budi Muhammad Taftazani, S.Sos, MPSSp.

Departemen Kesejahteraan Sosial FISIP Unpad

\section{Email: budi_taftazani@yahoo.com}

\begin{abstract}
ABSTRAK
Adanya perbedaan sudut pandang dalam memahami teori pada ilmu-ilmu sosial termasuk pekerjaan sosial seringkali memunculkan pertanyaan seperti: apa sebenarnya teori itu? Apakah pekerjaan sosial memiliki teori? Apa gunanya teori dalam praktik pekerjaan sosial?

Paling tidak dalam skema yang besar, pemahaman teori dapat berakar dari dua pandangan utama yang selama ini mempengaruhi pengetahuan pekerjaan sosial yaitu pemahaman teori yang berasal dari pandangan positivis atau modernis dan teori yang berasal dari pandangan posmodernis. Tentunya dilihat dari perjalanannya, teori dari aliran modernis-positivis adalah yang lebih dahulu berpengaruh, yang kemudian berkembang ke arah posmodernis.

Struktur pengetahuan positivisme yang dibangun dari tradisi ilmu alam dianggap kurang memadai dalam mengungkap kompleksitas gejala sosial atau interaksi dan perilaku manusia. Positivisme tidak sanggup mengungkap aspek-aspek yang tidak kasat mata dari fenomena sosial. Pengetahuan hanya sah bila sudah diuji oleh metode ilmiah. Sementara posmodernisme memberi ruang yang lebih terbuka dalam mengungkap aspek-aspek penting dibalik sebuah pengetahuan. Realitas tunggal, universalisme dan generalisasi yang luas ditolak oleh pandangan ini. Pengetahuan dianggap bukan gambaran sebenarnya dari realitas.

Implikasi pada pekerjaan sosial dari dua pandangan ini diantaranya adalah memperkaya conceptual framework dari pengetahuan pekerjaan sosial serta memberi kesadaran baru akan pentingnya memperhatikan konteks, lokalitas, keragaman, relativitas kebenaran pengetahuan, serta aspek-aspek penting lain dari kehidupan manusia atau dunia klien yang tidak terungkap oleh metode positivis. Terdapat pula relevansi pandangan posmodernisme dengan pekerjaan sosial sebagai ilmu terapan ketika pemaknaan teori tidak lagi dibatasi hanya sebagai penjelasan ekplanatif saja.
\end{abstract}

Kata Kunci : Teori Pekerjaan Sosial, Modernisme, Posmodernisme

\section{A. Teori Menurut Pandangan Positivis}

Positivisme adalah faham yang mendasarkan diri pada prinsip-prinsip ilmu pengetahuan alam, yaitu bahwa ilmu pengetahuan harus bersifat objektif, dapat digeneralisasi, dan diperoleh dengan menggunakan metode ilmiah. Pengetahuan menurut aliran positivis harus paling tidak memiliki syarat sebagai berikut :

1. Harus didukung oleh bukti yang diperoleh dari pengalaman atau observasi

2. Pengetahuan tersebut bukanlah berupa nilai, karena nilai tidak dapat diamati dan dibuktikan 
3. Harus menggunakan langkah-langkah sistematis yaitu berupa penerapan metoda ilmiah

Positivisme sejalan dengan faham modernisme, yang dimulai di zaman pencerahan Eropa (enlightment) abad enam belas dan tujuh belas, saat pengaruh agama dilepaskan dari ilmu pengetahuan. Maka demikian ilmu pengetahuan menurut faham modernis-positivis haruslah diperoleh melalui upaya-upaya penyelidikan terhadap fenomena alam atau sosial melalui proses riset. Aliran positivis percaya bahwa untuk memperoleh pengetahuan yang benar, maka pengetahuan tersebut haruslah dilepaskan dari nilai-nilai subjektif dan anggapan lain yang tidak dapat diamati.

Hammersley dan Atkinson (dalam Payne 1997:28), menyebutkan beberapa karakteristik dari metode positivis atau modernis dalam memperoleh pengetahuan yaitu:

1. Menggunakan model ilmu pengetahuan alam dalam semua reisetnya. Riset baru dikatakan valid jika menggunakan variabel-variabel dengan ukuran kuantitatif. Dengan demikian relasi manusia, budaya, masyarakat, dapat diteliti dengan cara seperti itu.

2. Menerapkan hukum universal, yaitu pandangan yang menggeneralisasikan sebuah kesimpulan untuk situasi yang lain. Menekankan pada kesamaan daripada melihat keunikan atau perbedaan yang dianggap tidak signifikan. Statistik digunakan dalam penelitian sosial sebagai dasar untuk menggeneralisasi

3. Observasi yang netral terhadap objek yang diteliti. Informasi-informasi yang tidak dapat terlihat atau tunggal diabaikan dengan penggunaan instrumen pengumpulan data yang sudah terstandar dan ditetapkan oleh peneliti.

4. Dapat meramalkan (teleology). Metode penelitian positivis dan modernis melihat bahwa masyarakat atau manusia akan bergerak menuju capaian-capaian sosial atau kemanusiaan seperti menuju modernitas, kebebasan, atau pemenuhan diri.

Teori yang dibangun dari penelitian modernisme atau positivisme adalah bersifat eksplanatif dan sebagai hasil dari prosedur ilmiah. Tripodi, Fellin, \& Meyer, 1969 dalam (Thyer, 2008) menjelaskan definisi teori menurut pandangan ini sebagai seperangkat hipotesis yang berhubungan secara logis yang menjelaskan relasi antar generalisasi yang sudah terbukti secara empiris. Sementara Tolson, Reid \& Garvin (1994), mendefinisikan teori sebagai seperangkat konsep dan konstruk yang menggambarkan dan menjelaskan sesuatu atau fenomena. Dalam faham positivis, teori menjelaskan mengapa sesuatu atau tindakan tertentu memunculkan akibat atau keadaan tertentu. Clark (1995) menggambarkan pemahaman ini dengan apa yang disebutnya sebagai penjelasan sebab akibat (causal narative), sedangkan Payne menyebutnya sebagai explanatory theory.

\section{Teori, Model, dan Perspektif}

Dalam pandangan positivisme yang harus selalu menerapkan metode ilmiah dalam membangun teorinya, maka teori merupakan sebuah pernyataan umum mengenai dunia nyata yang kebenarannya harus dapat dibuktikan melalui metode ilmiah. Berbeda dengan pandangan posmodernis yang memahami teori secara lebih longgar, pandangan positivis yang secara tegas mendasarkan pada metode ilmiah membedakan secara ketat antara teori, model, dan pendekatan atau perspektif.

Teori menurut pandangan positivis haruslah menjelaskan - berdasarkan hasil pembuktian-, mengapa sesuatu terjadi. Jadi teori menjelaskan sesuatu atau fenomena. Sedangkan model adalah sebuah acuan yang memberi panduan bagi praktik. Teori terdiri 
dari definisi dan proposisi, yaitu mendefinisikan, menjelaskan, dan memprediksi, namun tidak mengarahkan. Sebaliknya, model memberi penjelasan atau menentukan apa yang seharusnya dilakukan praktisi saat melakukan praktik. Model adalah pedoman untuk praktik. Tolson et al, (1994 dalam Thyer 2008), menjelaskan bahwa model, terdiri dari pernyataan-pernyataan yang memberi petunjuk atau langkah-langkah mengenai bagaimana intervensi seharusnya dilakukan.

Namun perlu juga dipahami bahwa model diperoleh dari teori atau berdasar teori namun cara mengembangkannya berbeda dengan teori. Loeb (1959) dalam Thyer 2008) menyebutkan bahwa model dibangun untuk memecahkan masalah secara langsung sehingga menghasilkan outcomes. Ia menyebut model sebagai alat pemecahan masalah (problem solving device).

Dari pemahaman teori dan model di atas, maka psikodinamika, behavioral, kognitif, konflik, fungsionalisme, modernisme, dan teori sistem adalah contohcontoh teori saat semuanya mendefiniskan, menjelaskan, dan memprediksi perilaku manusia atau gejala sosial. Namun pada tingkatan pemecahan masalah, maka terdapat pula model-model intervensi yang berasal dari teori-teori tersebut seperti model cognitivebehavioral treatment, model untuk perubahan komunitas dan organisasi, Welfare StateIndustry Model, Market Model, Charity Model, Activist Model, Task Centered, Case Management, Solution Focused, Intervensi Krisis, atau Self-Help Model.

Teori juga dibedakan dengan perspektif atau pendekatan. Perspektif merupakan sebuah cara melihat, yang mengarahkan pilihan pandangan kita dari berbagai variabel yang kompleks. Perspektif mengarahkan praktisi untuk memfokuskan perhatian pada faktor tertentu saja dari beragam variabel dalam situasi praktik. Sebuah perspektif adalah sebuah lensa untuk memotret satu angle saja dari sebuah landscape yang luas. Contoh dari perspektif adalah, ecological perspective, strength perspective, atau generalist perspective.

\section{B. Pengetahuan dan Teori Menurut Pandangan Posmodernis}

Sejak era 1990an, pekerjaan sosial mulai dipengaruhi oleh pemikiran posmodernisme. Posmodernisme sendiri adalah sebuah gerakan intelektual antitesa dari modernisme. Pemikiran ini melihat bahwa pengetahuan hanyalah gambaran dari realita yang tersusun dari simbol atau bahasa yang menggantikan realita. Dengan demikian, pengetahuan bukanlah realita yang sebenarnya. Karena tersusun dari simbol atau bahasa, maka ada proses komunikasi atau pertukaran simbol dan bahasa yang dilakukan manusia dalam mengembangkan pengetahuannya. Karena bahasa dapat dimaknai secara berbeda oleh manusia yang berbeda, maka pengetahuan yang ada bagaimanapun tidaklah bisa netral (sepeti yang diklaim oleh kaum positivis-modernis). Manusia dapat menciptakan bias pada bahasa yang mereka gunakan.

Bahasa dapat menggambarkan asumsi sosial yang berbeda dan manusia seringkali melakukan pemaknaan yang berbeda dari sebuah bahasa. Dengan demikian ide atau pengetahuan tidak bisa berdiri sendiri atau netral terhadap karakter, kepentingan, dan posisi sosial dari manusia saat mereka melakukan komunikasi dan memahami satu sama lain. Dengan demikian pengetahuan apapun bentuknya akan dipengaruhi oleh asumsi sosial tertentu.

Sebagai contoh, pada zaman orde baru, kelompok masyarakat yang mengalami kelaparan disebut oleh pemerintah atau media pada waktu itu sebagai kelompok yang mengalami 'rawan pangan'. Apa artinya ini? Bagaimana kita bisa melihat bahwa bahasa memiliki efek pencitraan dengan maksud tertentu oleh pusat kekuasaan. Atau bagaimana kita bisa menerima sebutan baru bagi kelompok pelacur menjadi 'pekerja seks komersial?' Hal yang sama juga terjadi dalam simbol (angka-angka) statistik, misalnya 
dalam menentukan apakah sebuah kelompok masyarakat termasuk dalam kategori miskin atau tidak. Terdapat perbedaan dalam ukuran atau kriteria yang menentukan siapa yang masuk dalam kategori miskin dan siapa yang tidak masuk dalam kategori miskin. Padahal ukuran miskin dan tidak miskin serta riset yang dilakukan untuk itu tentunya sudah menggunakan apa yang disebut sebagai 'metode ilmiah'. Contoh-contoh di atas menunjukan bagaimana simbol dan bahasa yang digunakan mempengaruhi persepsi, keadaan mental, dan tindakan-tindakan kita.

Karena dominasi saintific approach ini, maka banyak aspek yang tidak terlihat atau terungkap terkait fenomena kemiskinan. Harris (1999), menjelaskan sejak science ditetapkan sebagai satu-satunya upaya dalam rangka mencari jawaban terbaik, maka pada saat yang sama kita tidak bisa melihat berbagai perbedaan dan ini bisa membawa akibat pada intoleransi. Melalui kacamata posmodernisme, kepantasan atau kelayakan menurut pendekatan science seringkali membawa ketidakadilan pada kelompok atau manusia yang lain.

Bias kepentingan, misinterpretasi, dan pemaknaan relatif yang tercermin dari bahasa atau simbol seringkali terlewatkan oleh ide atau pengetahuan modern (positivistik). Masalah terpentingnya adalah bahwa bahasa, simbol, atau pengetahuan tersebut mengandung ide tertentu sehingga sekaligus mengarahkan tindakan atau keputusan manusia seperti pada pola-pola relasi sampai pengambilan keputusan atau kebijakan. Posmodernisme menolak generalisasi yang luas (totalizing theories) seperti itu sehingga menolak science sebagai satu-satunya kebenaran yang mutlak.

\section{Pengetahuan Sebagai Hasil Konstruksi Sosial}

Pandangan posmodernis melihat bahwa pengetahuan itu mengandung makna (meaning), dan bukanlah sekedar data-data empiris dan bersifat objektif seperti yang diyakini kaum positivis. Posmodernis menghargai adanya keragaman dan kompleksitas pengetahuan atau pengalaman, serta melihat adanya saling mempengaruhi antara ide dan situasi sosial. Dengan demikian tidak ada realitas tunggal dalam pandangan posmodernis, - tidak seperti pandangan positivis yang melihat bahwa pengetahuan yang benar harus mengandung unsur universalitas, objektivitas dan dapat di generalisasi-.

Namun hal ini bukan berarti bahwa pandangan posmodernis tidak dapat menciptakan kesamaan-kesamaan mengenai ide atau pengetahuan. Payne (1997), menjelaskan bahwa kaum posmodernis tidaklah berpendapat bahwa kesepakatan mengenai teori untuk bertindak mustahil untuk dicapai. Sebaliknya, mereka beranggapan bahwa orang memahami sesuatu dengan cara menerima gambaran-gambaran dunia yang secara sosial disepakati dan diterima sebagai realita.

Lantas siapa yang menciptakan kesepakatan, dan bagaimana kesepakatan itu bisa tercapai? Jawabannya terletak pada proses relasi kekuasaan. Pengetahuan adalah ide-ide tentang dunia yang dikonteskan melalui pertukaran atau interaksi bahasa, sehingga muncul makna-makna yang disepakati secara sosial. Proses relasi ini menyebabkan satu ide atau pengetahuan dapat diterima dalam satu kelompok masyarakat atau individu, atau dianggap lemah bahkan ditolak. Ketika satu ide diterima, maka pengetahuan tersebut memiliki kekuatan (power). Inilah yang yang dimaksud pengetahuan yang dihasilkan dari konstruksi sosial. Pengetahuan bukanlah realita sesungguhnya melainkan seperangkat ide yang muncul dari hasil berbagai proses sosial (melalui dialog/debat dan tindakan/praktik) sehingga muncul kesepakatan sosial mengenai ide tersebut.

Pertanyaannya adalah apakah pengetahuan yang dibangun berdasarkan konstruksi sosial bisa objektif ? Hal penting untuk menjawab ini adalah kita harus membedakan makna objektivitas antara pengetahuan alam dengan pengetahuan sosial. Berbeda dengan pandangan positivis yang 
menyandarkan makna objektivitas pengetahuan sosial sesuai dengan makna objektivitas pada pengetahuan alam, maka pandangan posmodernis memaknai objektivitas pengetahuan sosial berdasarkan pada konstruksi sosial. Payne (2005) menjelaskan ketika pengetahuan merupakan representasi dari realita yang kita terima dari berbagai proses sosial sehingga ditemukan pandangan yang sama, maka pengetahuan tersebut menjadi objektif. Kita juga melembagakan kesepakatan tersebut sesuai dengan kesamaan pengertian dari banyak orang, sehingga pengertian-pengertian tersebut menjadi terlegitimasi. Pada gilirannya ide-ide tersebut menjadi terorganisir dan menjadi sistem yang masuk akal serta dijadikan panduan untuk bertindak.

Dengan demikian pengertianpengertian mengenai sesuatu menjadi objektif karena merupakan pengetahuan yang dapat diterima oleh sekelompok orang atau sekelompok masyarakat. Namun karena setiap orang, setiap kelompok, atau setiap masyarakat memaknai realita menjadi pengertian atau ide-ide yang berbeda (berdasarkan kesepakatan masing-masing) maka akan terlihat banyak pandangan yang berbeda, banyak 'objektivitas' yang berbeda dan khas sesuai konteksnya masing-masing.

Dalam posmodernine tidak mengenal teori universal. Konteks sejarah dan budaya membawa variasi dalam pengetahuan pekerjaan sosial termasuk fenomena pekerjaan sosial itu sendiri. Ketika masyarakat dibangun dari keadaan sosiokultural yang berbeda, posmodernisme menentang beragam bentuk dominasi pengetahuan universal. Dalam kajian pekerjaan sosial internasional, Payne \& Askeland (2008) misalnya memahami bahwa kajian pekerjaan sosial internasional ikut mengkritisi apakah model praktik dan organisasi pekerjaan sosial Barat berlaku universal dalam aplikasinya. Mereka melihat perlunya sebuah framework untuk memahami pekerjaan sosial secara berbeda yang memperhatikan asumsi-asumsi kultural dan kebutuhan sosial.

\section{Teori Menurut Pandangan Posmodernis}

Karena posmodernisme mendasarkan pada ide konstruksi sosial, maka teori tidak hanya berupa penjelasan eksplalnatif atau causal narative saja seperti yang dianggap oleh positivisme. Menurut posmodernisme, teori merupakan generalisasi yang bisa mencakup tiga kemungkinan yaitu model, perspektif, dan teori eksplanatif (Payne 2005:4). Meskipun ketiga istilah tersebut memiliki arti yang agak berbeda, namun seringkali disatukan dalam istilah teori (Sheafor \& Horesjsi, 2012:34).

Pekerjaan sosial adalah ilmu terapan sehingga dalam aktivitas praktik, sulit jika dilakukan pemisahan dari ketiga bentuk teori tersebut. Dalam praktik yang baik, pekerja sosial tidak bisa hanya mengandalkan pada teori-teori eksplanatif atau perspektif saja. Pekerja sosial juga butuh model sebagai panduan untuk bertindak.

Teori, model, dan perspektif kegunaannya bukan sekedar untuk saling melengkapi satu sama lain namun juga dapat saling menguatkan satu sama lain. Payne (1997) menjelaskan, teori atau perspektif tidak akan berarti apa-apa dalam praktik jika tidak dilengkapi model sebagai panduan bertindak. Begitu pula model tidak akan benar dan efektif jika tidak didasari oleh bukti-bukti kuat sehingga diperlukan teori eksplanatif. Model dan teori eksplanatif akan memiliki konsistensi dalam keluasan kajian pekerjaan sosial dan memiliki kegunaan secara umum jika menawarkan cara pandang (way of thinking) yang dapat memungkinkan kita mentransfer ide-ide pada berbagai situasi serta dapat membentuk pola praktik.

\section{Relasi Teori dan Praktik Dalam Pekerjaan Sosial}

Pekerjaan sosial adalah jenis ilmu terapan. Artinya teori-teori pekerjaan sosial tidak bisa dipisahkan dari praktik pekerjaan sosial, atau dalam pekerjaan sosial tidak bisa dipisahkan antara konsep dari aksi. Kita tidak 
belajar teori yang tidak bisa digunakan untuk kepentingan praktik atau tidak memberi pemahaman pada praktik pekerjaan sosial. Sebagai ilmu terapan, teori pekerjaan sosial dapat dibangun dari lapangan praktik.

Praktik merupakan proses penggunaan pengetahuan dan penerapan teori agar menghasilkan sebuah perubahan. Praktik tanpa teori cenderung seperti ritual dan tidak efektif, sedangkan teori tanpa berlandaskan informasi dari kenyataan praktik, cenderung hanya menarik dan biasanya tidak relevan.

Beberapa penulis dalam pekerjaan sosial mendefinisikan teori diantaranya sebagai berikut: Teori adalah sekumpulan ide atau prinsip yang digunakan untuk pedoman praktik. Ide-ide ini harus jelas dan masuk akal sehingga terbuka untuk ditantang (Beckett, 2006); sedangkan Payne (2005) mendefinisikan teori sebagai pernyataan ideide yang terorganisir mengenai dunia.

Seperti penjelasan sebelumnya mengenai perbedaan pandangan teori menurut positivisme dan posmodernisme, maka penulis memilih pengertian teori dari pandangan posmodernis. Definisi posmodernis menunjukan bahwa teori bukanlah sekedar causal narrative (seperti versi positivis), melainkan sebagai pedoman praktik. Teori menjadi tidak berguna dalam pekerjaan sosial jika tidak ada relevansinya dengan praktik pekerjaan sosial.

Sebuah teori dapat dikonteskan melalui upaya pengajuan argumen atau keberatan yang berdasarkan pada temuantemuan praktik. Orang dapat menantang teori yang ada dengan mengajukan argumen yang berbeda. Pada banyak situasi pekerja sosial seringkali mendasarkan pada teori mereka sendiri yang dibangun berdasarkan pengalamannya, hasil diskusi dengan pekerja sosial lain, dan dari sumber-sumber lain di luar sumber-sumber akademik. Proses konstruksi sosial ini terus terjadi dalam siklus konstruksi-praktik-rekonstruksi, dan seterusnya.
Beckett (2006), menyarankan bahwa tindakan pekerja sosial sebaiknya didasarkan pada ide-ide berikut,

1. Dalam situai seperti ini apa isu utamanya?

2. Apa yang dapat membantu? dan mengapa itu dapat membantu?

Pekerja sosial dapat mengajukan teori mengenai apa sebenarnya kesulitan atau kebutuhan yang dihadapi. Selanjutnya pekerja sosial mengajukan teori berikutnya, apa yang dapat membantu memenuhi kebutuhan atau mengatasi masalah tersebut? Jika itu adalah ('X'), mengapa itu dapat membantu?

Kedua pernyataan di atas dapat dikonteskan sehingga bisa menghasilkan kesimpulan yang baru atau yang berbeda. Orang yang tidak setuju dapat mengajukan bukti atau saran bahwa misalnya, kesulitannya bukanlah ' $\mathrm{Y}$ '; atau ' $\mathrm{X}$ ' tidaklah membantu meskipun masalahnya adalah ' $Y$ '.

Dalam pekerjaan sosial, teori akan diterapkan secara terus menerus di wilayah praktik dan penerapan suatu teori adalah sama dengan menguji teori tersebut sampai dilakukan evaluasi sehingga dapat diketahui apakah sebuah teori dianggap masih memadai atau tidak. Dari sinilah maka satu teori harus dapat di 'challenge' atau dikonteskan dengan anggapan baru, fakta baru, berbagai konteks seperti tempat dan waktu, sejarah, keadaan sosial politik, dan budaya.

Dunia pendidikan memungkinkan kita untuk saling mengajukan argumen dalam menguatkan posisi teori yang kita pilih. Siklus konstruksi-praktik-rekonstruksi mensyaratkan situasi dialog yang terbuka dan fair. Turner (1996:11), menjelaskan bahwa kita dapat menjelaskan aktivitas praktik pada yang lain, mentransfer pengetahuan dan keterampilan kita yang sudah terlihat dan teruji di lapangan, serta sudah barang tentu aktivitas kita tersebut dapat dievaluasi dan diteliti kembali secara lebih cermat oleh orang lain. 


\section{Tindakan Berteori}

Apa bedanya teori dalam pekerjaan sosial dengan teori dari disiplin lain? Perlu dijelaskan di sini bahwa teori-teori dalam pekerjaan sosial hanya berhubungan dengan apa yang pekerja sosial lakukan (praktik) serta yang berkaitan dengan faktor-faktor yang menentukan keberhasilan atau akibat lain dari praktik yang dilakukan. Sudut pandang posmodernisme sejalan dengan pekerjaan sosial sebagai ilmu terapan karena pandangan ini memaknai teori bukan sekedar penjelasan eksplanatif atau causal narrative saja, melainkan termasuk di dalamnya model yang digunakan sebagai panduan untuk bertindak

Intervensi pekerjaan sosial adalah tindakan berteori. Kajian penting sebelum pekerjaan sosial melakukan tindakan atau praktiknya adalah menentukan terlebih dahulu apa isu utama yang akan ditangani, apa yang dapat membantu untuk menangani isu tersebut, dan mengapa itu dapat membantu. Upaya untuk menjawab pertanyaanpertanyaan ini adalah tindakan atau aktivitas berteori. Dalam aktivitas ini, pekerja sosial mencari, memilih dan menggunakan teori yang relevan sebelum melakukan tindakan praktik.

Jika pekerja sosial hanya memiliki teori ekplanatif saja maka praktik tidak bisa dilakukan karena teori eksplanatif tidak memberi pedoman untuk aksi. Seandainya demikian faktanya maka pekerjaan sosial bukanlah ilmu terapan. Kenyataanya selain memiliki teori dengan bentuk eksplanatif atau causal narative, pekerjaan sosial seperti yang sudah dijelaskan sebelumnya juga memiliki bentuk teori yang lain yaitu perspektif dan model. Disinilah terlihat relevansi pemaknaan teori yang lebih longgar dari pandangan posmodernisme dengan pekerjaan sosial sebagai ilmu terapan.

Selain menggunakan teorinya sendiri, pekerjaan sosial juga menggunakan konsep atau teori yang berasal dari ilmu-ilmu murni. Teori yang berasal dari ilmu lain termasuk ilmu murni adalah pinjaman.
Namun tetap saja bahwa teori yang dipilih dari ilmu murni tersebut harus terkait dengan kepentingan praktik. Maas (1996, dalam Shulman 1991), menjelaskan bahwa konsepkonsep dan kajian ilmu lain termasuk ilmu murni seperti sosiologi, psikologi, ekonomi, antropologi, biologi, medis, hukum, dan disiplin lain hanya berguna jika dapat meningkatkan pemahaman pada praktik pekerjaaan sosial, termasuk pemahaman pada apa yang pekerja sosial lakukan, mengapa mereka melakukan itu, serta apa efek dari tindakan yang mereka lakukan itu. Dengan demikian pekerja sosial tidak mempelajari ilmu-ilmu lain hanya sekedar untuk memperoleh pemahaman belaka, namun ilmu lain tersebut digunakan untuk kepentingan mencapai praktik terbaiknya.

Teori-teori yang dipinjam dari ilmu murni umumnya adalah perspektif dan teori eksplanatif yang menyediakan pengetahuan dasar yang penting dan dikategorikan sebagai Orienting Theories yang merupakan bagian dari conceptual framework dalam pekerjaan sosial. Semua teori, model, dan persepktif yang terdapat dalam literatur pekerjaan sosial disebut sebagai conceptual framework yaitu serangkaian konsep, keyakinan, nilai, proposisi, asumsi, hipotesis, dan prinsipprinsip. (Sheafor \& Horesjsi, 2012).

Pekerjaan sosial adalah ilmu terapan yang memiliki tujuan untuk perubahan atau menghasilkan tindakan, bukan sekedar untuk memahami fenomena sosial. Dari sini sekaligus dapat dijelaskan pula bahwa lulusan studi pekerjaan sosial adalah para profesional, bukan sekumpulan akademisi yang hanya melakukan kajian-kajian tanpa memberikan pelayanan sosial atau aksi perubahan.

\section{Daftar Pustaka}

Beckett, Chris (2006). Essential Theory for Social Work Practice. London : Sage Publication Ltd. 
Bruce A., Thyer (2008). Comprehensive Handbook of social Work and Social Welfare : Human Behavior in The Social Environment. John Wiley \& Sons, Inc.

Harris, Marvin (1999). Theories of Culture in Postmodern Times. Altamira, Sage Publications, Inc

Payne, M. \& Askeland A. Gurid (2008). Globalization and International Social Work: Posmodern Change and Challenge.Ashgate Publicing Limited.

Payne, Malcolm (1997). Modern Social Work Theory. Macmillan Press Ltd.

(2005). Modern Social Work Theory. Palgrave Macmillan.

Sheafor \& Horesjsi (2012). Techniques and Guidelines for Social Work Practice. Pearson Education, Inc.

Shulman, Lawrence (1991). Interactional Social Work Practice : Toward an Empirical Theory. F.E.Peacock Publishers, Inc.

Turner, Francis J (1996). Social Work Treatment : Interlocking Theoritical Approaches. New York: The Free Pres. 